\title{
PEMANFAATAN TEKNOLOGI VACUUM FRYING UNTUK MENDUKUNG DIVERSIFIKASI PRODUK OLAHAN MAKANAN RINGAN PADA UKM DI KEC. KOTO BALINGKA, KAB. PASAMAN BARAT, PROV. SUMATERA BARAT
}

\section{UTILIZATION OF VACUUM FRYING TECHNOLOGY TO SUPPORT SNACK PRODUCTS DIVERSIFICATION OF SME IN KOTO BALINGKA, PASAMAN BARAT DISTRICT, WEST SUMATRA}

\author{
Andasuryani $^{1)}$, Alhapen Ruslin Chandra ${ }^{2)}$, Renny Eka Putri ${ }^{1)}$ \\ ${ }^{1)}$ Jurusan Teknik Pertanian Universitas Andalas, Kampus Limau Manis, Padang 25163, \\ Indonesia \\ E-mail: andasuryani@ae.unand.ac.id; rennyekaputri@ae.unand.ac.id \\ ${ }^{2)}$ Jurusan Administrasi Niaga, Politeknik Negeri Padang, Kampus Limau Manis, Padang \\ 25163, Indonesia \\ E-mail: alhapen@polinpdg.ac.id
}

\begin{abstract}
ABSTRAK
Potensi hasil pertanian yang ada di kecamatan Koto Balingka,Kab. Pasaman Barattelah dimanfaatkan oleh masyarakat sekitarnya dengan melakukan kegiatan pengolahan hasil pertanian menjadi produk olahan makanan ringan seperti keripik. Pada umumnya, bentuk kegiatan usaha yang dilakukan oleh masyarakat masih dalam skala rumah tangga, seperti yang dikelola oleh UKM Umak Havis dan UKM Umak Buyung. Kedua UKM ini, tepatnya berada di Jorong Lubuk Gadang, kecamatan Koto Balingka.Kedua UKM ini hanya menggunakan komoditi pisang dan ubi kayu sebagai bahan baku pembuatan keripik. Ketergantungan UKM sangat tinggi terhadap komoditi pisang dan ubi kayu. Sementara itu, keberadaan hasil hortikultura lainnya dapat menjadi bahan baku alternatif dalam mendiversifikasikan produk olahan mereka selain pisang dan ubi kayu. Proses produksi dan pengemasan produk yang dilakukan pada kedua UKM ini menunjukkan belum adanya sentuhan teknologi sehingga produk yang dihasilkan memiliki daya saing yang rendah. Melalui kegiatan PKM ini ditawarkan solusi dalam bentuk menyediakan teknologi penggorengan berupa alat vaccum frying dan spinner serta teknologi pengemasan menggunakan hand sealer. Kegiatan ini dilaksanakan dalam beberapa tahapan yang meliputi tahap pembuatan alat vaccum frying dan spinner, tahap evaluasi kinerja alat, dan tahap introduksi alat dan teknologi pengemasan kepada mitra. Kapasitas maksimum alat vacuum frying adalah $1.5 \mathrm{~kg}$ dengan dimensi total $470 \mathrm{~mm}$ x $390 \mathrm{~mm}$ x $940 \mathrm{~mm}$ (p x 1 x t). Sementara itu, spinner dibuat dengan ukuran $450 \mathrm{~mm}$ x $390 \mathrm{~mm}$ x $800 \mathrm{~mm}$ dengan daya motor penggerak 400 watt. Kegiatan introduksi berjalan dengan lancar dan mitra tertarik dan antusis. Kegiatan ini menambah pengetahuan mitra dalam mendiversifikasikan produk olahan dan proses tranfer teknologi pengemasan sehingga dapat membantu mitra dalam melakukan pengemasan produk yang lebih menarik bagi konsumen.
\end{abstract}

Kata kunci: Diversifikasi Produk, Teknologi Pengemasan, Vaccum Frying, Spinner.

\section{ABSTRACT}

Agricultural products in Koto Balingka sub-district has been used by community by processing the products into snacks such as chips. Generally, the business carried out by the community were in a household scale, such as Small Medium Enterprise (SME) Umak Havis and SME Umak Buyung. These two SMEs, located in Lubuk Gadang vilage, Koto Balingka 
sub-district. These SMEs only use banana and cassava as a raw material for producing the chips. The dependence of SMEs was very high on the commodity of bananas and cassava. Meanwhile, the presence of other horticultural products could be an alternative raw material in diversifying their processed products. Previously, there is no technology apllied in the production and packaging process carried out on these two SMEs. Therefore, this Community Development Activity offered a solution by providing frying technology consists of a frying and spinner vaccum device and packaging technology using hand sealer. This activity was carried out in several stages which are building the frying and spinner vaccum device, evaluation of devices performance, and introducing the device and packaging technology to partners. The maximum capacity of a vacuum frying device is $1.5 \mathrm{~kg}$ with a total dimension of $470 \mathrm{~mm} \times 390 \mathrm{~mm} \times 940 \mathrm{~mm}$ ( p x l $\times$ t). Meanwhile, spinner dimension was $450 \mathrm{~mm} \times 390 \mathrm{~mm}$ $x 800 \mathrm{~mm}$ with a power of 400-watt drive motor. The introduction activities conducted smoothly, and the partners showed their interest and enthusiasm. The activity has broadened the knowledge of partners in diversifying processed products. In addition, it also improves their product packaging become more attractive for the consumer.

Keywords: Product Diversification, Packaging Technology, Vaccum Frying, Spinner.

\section{PENDAHULUAN}

Sektor pertanian merupakan sektor utama lapangan usaha bagi masyarakat di kecamatan Koto Balingka, Kab. Pasaman Barat. Salah satu jenis hortikultura yang dibudidayakan oleh masyarakat di kecamatan Koto Balingka adalah pisang. Berdasarkan data BPS (2017), kecamatan Koto Balingka pada tahun 2015 telah memproduksi pisang sebesar 35ton dengan luas tanam dan luas panen masingmasingnya $1 \mathrm{Ha}$. Produksi ini termasuk kecil jika dibandingkan dengan kecamatan lainnya yang ada di kabupaten Pasaman Barat. Disamping itu, komoditi ubi kayu juga diusahakan oleh masyarakat di kecamatan Koto Balingka. Produksi ubi kayu di kecamatan Koto Balingka adalah sebanyak 317 ton dengan luas tanam dan luas panen berturut-turut sebesar $12 \mathrm{Ha}$ dan 9 Ha (BPS, 2017). Berdasarkan potensi hasil pertanian yang ada di kecamatan Koto Balingka, maka masyarakat di daerah ini telah memanfaatkan peluang usaha dengan melakukan kegiatan pengolahan hasil pertanian tersebut menjadi produk olahan makanan ringan seperti keripik. Bentuk kegiatan usaha yang dilakukan oleh masyarakat masih dalam skala rumah tangga, seperti yang dikelola oleh UKM Umak Havis dan UKM Umak Buyung. Kedua UKM ini, tepatnya berada di Jorong Lubuk Gadang, kecamatan Koto Balingka.

Kedua UKM ini hanya menggunakan komoditi pisang dan ubi kayu sebagai bahan baku pembuatan keripik. Jenis pisang yang digunakan tidak hanya satu jenis saja namun bervariasi seperti pisang nangka, pisang kepok, pisang ambon dan pisang tanduk. Proses produksi dilakukan seminggu sekali dengan jam kerja 10 jam/ hari dengan ratarata produksi sebesar 100-150 kg/hari atau tergantung ketersediaan bahan baku.

Tahapan proses produksi keripik pisang dan ubi kayu yang dilakukan pada kedua UKM ini adalah pengupasan kulit, 
pencucian, perajangan/ pengirisan, teknologi pengemasan produk.

penggorengan dan pengemasan. Pada proses penggorengan, UKM ini menggunakan tunggu sederhana dengan kayu sebagai bahan bakar (Gambar 1). Sementara itu, peralatan yang digunakan adalah pisau pengupas, alat pengiris manual, wajan dan saringan minyak atau peniris (Gambar 2). Kondisi ini menggambarkan belum adanya sentuhan teknologi pada proses produksi keripik sehingga menghasilkan produk dengan daya saing yang rendah.

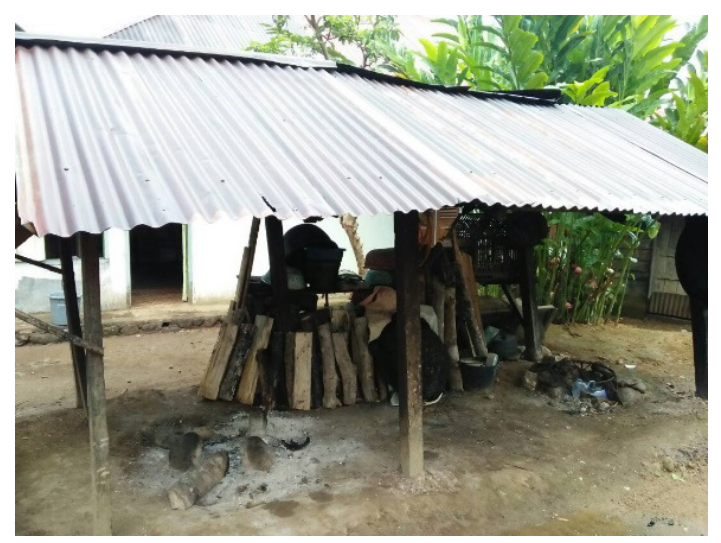

Gambar 1. Tempat proses penggorengan keripik milik mitra

Proses pengemasan tidak langsung selesai dalam waktu satu hari sehingga keripik yang telah dihasilkan hanya dimasukkan ke dalam plastik berukuran besar dan diikat. Pengemasan menggunakan kemasan plastik berukuran kecil akan dilakukan pada harihari berikutnya. Kemasan yang digunakan adalah plastik pp $1 / 2$ ons ukuran $5.5 \mathrm{~cm}$ x 10 cm dan tanpa menggunakan label pada kemasan. Gambar 3 memperlihatkan jenis dan bentuk kemasan keripik yang dihasilkan oleh UKM. Kondisi ini juga menggambarkan belum adanya sentuhan
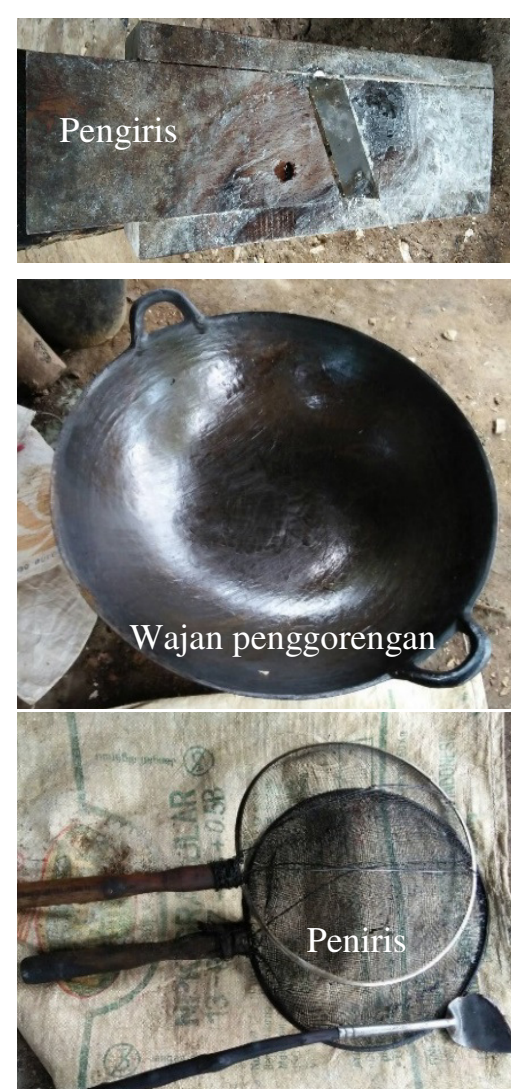

Gambar 2. Peralatan yang digunakan mitra dalam proses penggorengan keripik

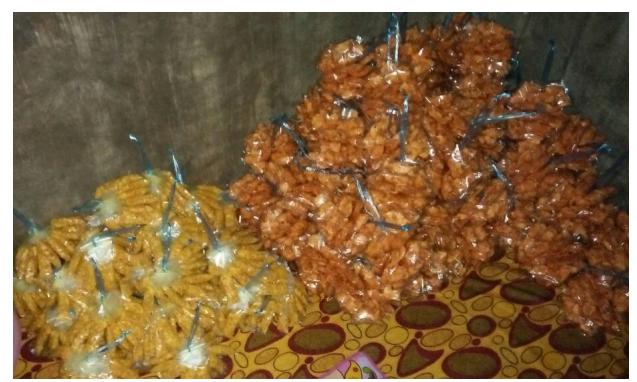

Gambar 3. Jenis dan bentuk kemasan keripik produksi UKM

Ketergantungan UKM sangat tinggi terhadap komoditi pisang dan ubi kayu. Sementara itu, keberadaan hasil hortikultura lainnya seperti terung, ketimun, kacang panjang, bayam merah, kangkung, jeruk dan pepaya cukup tinggi di daerah Kota Balingka ini. Komoditi-komoditi tersebut dapat menjadi bahan baku alternatif dalam mendiversifikasikan produk olahan mereka 
selain pisang dan ubi kayu.

Berdasarkan pada permasalahan ke dua UKM ini, maka tim pelaksana kegiatan PKM menawarkan solusi dalam bentuk menyediakan teknologi penggorengan berupa mesin vaccum frying dan spinner serta teknologi pengemasan menggunakan hand sealer. Penggorengan vakum merupakan proses yang dapat mempertahankan nilai gizi dari sayursayuran dan buah-buahan. Buah-buahan atau sayur-sayuran didehidrasi tanpa mengalami reaksi pencoklatan (browning) atau produk menjadi hangus (Setyawan dan Widaningrum, 2013). Pada operasi penggorengan vakum, bahan pangan mentah dipanaskan di bawah kondisi tekanan yang diturunkan $(<60$ Torr $\sim 8 \mathrm{kPa})$ yang dapat menurunkan titik didih minyak dan kadar air bahan pangan tersebut (Shyu et al. ,1998) Produk yang dihasilkan dengan menggunakan teknologi vacuum frying menurut Lastriyanto (1997) memiliki tekstur dan warna yang lebih bagus, penyerapan minyak yang rendah, kerusakan vitamin rendah, sehingga produk memiliki mutu dan tingkat kesehatan yang baik. Disamping itu, Shyu dan Hwang (2001), Garayo dan Moreira (2002), Granda et al. (2004) dan Troncoso dan Pedreschi (2009) menyatakan bahwa teknologi vacuum frying merupakan salah satu upaya untuk mengurangi minyak pada produk yang dihasilkan. Sementara itu, Setyawan dan Widaningrum (2013) menyatakan bahwa proses penggorengan sayur dan buah secara konvensional akan menghasilkan mutu yang rendah karena penggorengan dilakukan pada suhu yang cukup tinggi $\left( \pm 160-180^{\circ} \mathrm{C}\right)$ yaitu pada suhu titik didih minyak. Proses pengolahan sayur dan buah jika dilakukan secara konvensional maka rasa dan aromanya akan berubah artinya tidak sesuai dengan rasa buah aslinya dan produk yang dihasilkanpun tidak homogen.

Kegiatan ini dilaksanakan dengan tujuan untuk mengintroduksikan teknologi vaccum frying dan spinner serta teknologi pengemasan menggunakan hand sealer. Manfaat kegiatan ini adalah dapat membantu mitra dalam menghasilkan produk yang lebih berkualitas dan adanya diversifikasi produk dengan memanfaatkan bahan baku sayur dan buah yang ada disekitar mitra.

\section{METODE PELAKSANAAN}

Kegiatan pengabdian ini dilaksanakan selama empat bulanyang dimulai dari bulan April sampai Juli 2018. Tahapan kegiatan ini meliputi:

a) Tahap pembuatan alat vaccum frying dan spinner.

b) Tahap evaluasi kinerjaalat dan analisa ekonomi.

c) Tahap introduksi alat vaccum frying dan spinner dan teknologi pengemasan menggunakan hand sealer dalam upaya meningkatkan kualitas produk dan kegiatan pemasaran UKM mitra.

Pembuatan alat vaccum frying dan spinner dilakukan di bengkel Daud Teknik Maju 
Pratama Bogor. Setelah alat selesai dibuat, dilanjutkan dengan pengujian alat dengan menggunakan terung ungu. Pengujian dilakukan dengan menggunakan suhu $80^{\circ} \mathrm{C}$ selama 1.5 jam. Parameter yang digunakan untuk mengevaluasi mutu keripik yang dihasilkan meliputi rendemen, kadar air, lemak, protein, kadar abu dan karbohidrat. Data yang diperoleh diolah dengan analisis statistik deskripstif yang meliputi rata-rata dan standar deviasi.

\section{HASIL DAN PEMBAHASAN}

\section{a) Alat Vaccum Frying dan Spinner}

Alat vaccum frying yang dibuat terdiri dari beberapa komponen, yaitu (a) sumber panas berupa gas elpiji (b) tabung penggoreng, (c) keranjang penampung bahan, (d) tuas pengaduk, (e) kontrol suhu, (e) kondensor, dan (f) pompa sirkulasi. Kapasitas alat vacuum frying adalah $1.5 \mathrm{~kg}$ dengan dimensi total $470 \mathrm{~mm}$ x $390 \mathrm{~mm}$ x $940 \mathrm{~mm}(\mathrm{p} \times 1 \times \mathrm{t})$. Alat vacuum fryingini dilengkapi dengan kontrol suhu. Daya pompa vakum adalah 400 watt.

Sementara itu, spinner dibuat dengan ukuran $450 \mathrm{~mm}$ x $390 \mathrm{~mm}$ x $800 \mathrm{~mm}$ dengan daya motor penggerak 400 watt. Keranjang penampung bahan dibuat dengan ukuran diameter $200 \mathrm{~mm}$ dan tinggi $170 \mathrm{~mm}$. Keranjang penampung bahan pada alat vacuum frying juga dapat digunakan pada spinner tanpa harus memindahkan produk. Bahan tabung penggoreng dan kondensor terbuat dari stainless steel sedangkan rangka dibuat dari besi yang dicat. Gambar 4 dan
Gambar 5 memperlihatkan alat vaccum frying dan spinner.

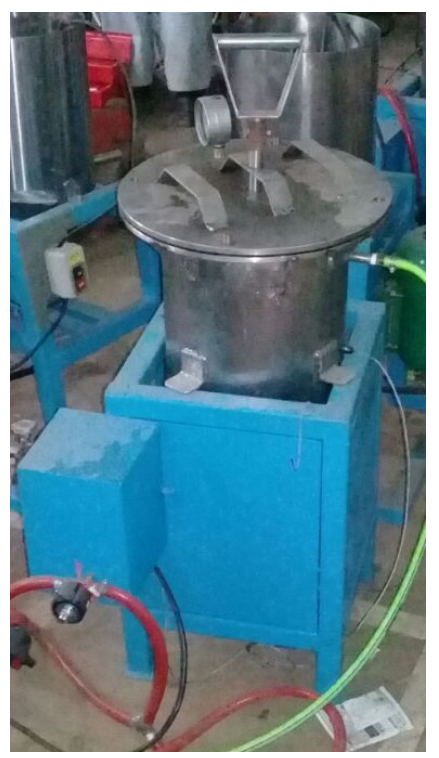

Gambar 4. Alat vacuum frying

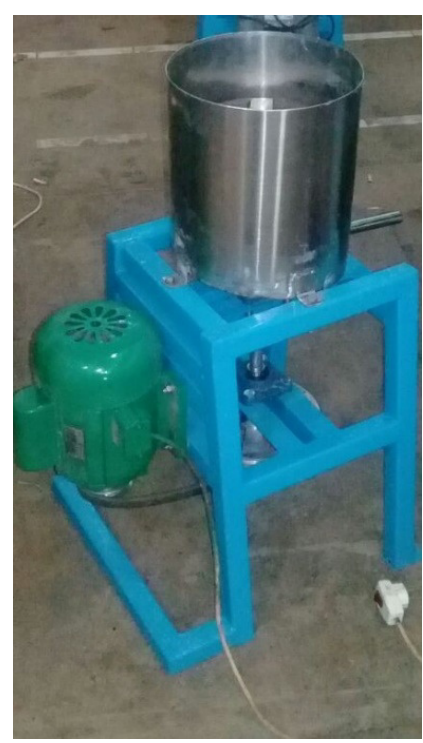

Gambar 5. Spinner

\section{b) Evaluasi Kinerja Alat dan Analisa Ekonomi}

Hasil pengujian kinerja alat vacuum fryingdalam pembuatan keripik terung (Tabel 1) memperlihatkan nilai rendemen sebesar $37.33 \%$. Nilai ini lebih tinggi dari rendemen pembuatan sayuran kering wortel $(14.88 \%$ s/d $16.56 \%$ dengan waktu penggorengan berlangsung selama 1.32 jam s/d 1.67 jam.) 
dan buncis $(13.58 \%$ s/d $14.17 \%$ dengan waktu penggorengan vakum berlangsung selama $1.08 \mathrm{jam}$ s/d 1.41 jam) (Setyawan et al., 2007 dalam Widaningrum \& Setyawan 2009).

Tabel 1. Evaluasi kinerja alat vacuum frying dan mutu keripik terung

\begin{tabular}{ll}
\hline Parameter & Nilai \\
& \\
\hline Rendemen (\%) & $37.33 \pm 1.53$ \\
Kadar air (\%) & $7.32 \pm 1.70$ \\
Kadar lemak (\%) & $41.56 \pm 7.06$ \\
Kadar protein (\%) & $2.40 \pm 0.26$ \\
Kadar abu (\%) & $1.92 \pm 0.91$ \\
Kadar karbohidrat (\%) & $46.81 \pm 6.13$
\end{tabular}

${ }^{\mathrm{I}}$ Rata-rata \pm standar deviasi $(\mathrm{n}=3)$

Nilai kadar air keripik terung (7.32\%) lebih tinggi dibandingkan dengan SNI untuk beberapa jenis keripik seperti keripik pisang dan keripik singkong (maksimum 6\%), keripik sukun (maksimum 5\% dan keripik tempe (maksimum 3\%), namun nilai kadar air ini hampir sama dengan keripik buncis yaitu 7.18\% (Setyawan et al., 2007 dalam Widaningrum \& Setyawan 2009).

Begitupun untuk kandungan lemak (41.56\%) cukup tinggi jika dibandingkan dengan SNI untuk beberapa jenis keripik. Menurut Rukmana (1995), kandungan lemak dalam $100 \mathrm{~g}$ terung segar adalah $0.2 \mathrm{~g}$. Ini berarti kandungan lemak dalam terung segar sebesar 2\%. Namun ketika dioleh menjadi keripik, kandungan lemaknya meningkat. Hal ini terjadi karena masuknya minyak ke dalam keripik yang terjadi akibat hilangnya air melalui permukaan dan penyerapan minyak ini berhubungan dengan kehilangan air (Shyu dan Hwang, 2001).

Kandungan protein dalam $100 \mathrm{~g}$ terung segar adalah 1 g (Rukmana, 1995) dan nilainya meningkat setelah digoreng. Peningkatan ini dapat disebabkan karena adanya penambahan bahan lain yang mengandung protein (Elinda, 2007). Sama halnya, dengan kandungan lemak dan protein, kandungan abu juga meningkat setelah penggorengan. Kandungan abu dalam keripik terung (1.92\%) lebih kecil dibandingkan dengan keripik buncis (5.19\%) (Setyawan et al., 2007 dalam Widaningrum \& Setyawan 2009) dan SNI untuk keripik pisang, tempe dan singkong yang berturutturut adalah maksimum $8 \%, 3 \%$ dan $5 \%$. Sementara itu, kandungan karbohidrat pada keripik terung ini cukup tinggi $(46.81 \%)$ jika dibandingkan dengan SNI keripik sukun (min $30 \%)$.

Hasil analisa ekonomi dengan menggunakan bahan baku terung ungu memperlihatkan bahwa usaha ini layak untuk dijalankan berdasarkan kriteria kelayakan usaha yaitu NPV positif, IRR > bunga bank dan PI $>$ 1. Perkiraan jumlah produksi 60 bungkus per hari dan harga jual Rp 5 000,per bungkus maka didapatkan penjualan $\mathrm{Rp}$ 300 000,- per hari. Dengan demikian, besarnya penjualan perbulan (30 hari) adalah Rp 9000 000,-. Jika selama 36 bulan dengan tingkat bunga $1 \%$ per bulan atau $12 \%$ per tahun, maka didapatkan NPV sebesar Rp 14 
235 247,- dan IRR sebesar 5,484\% per bulan atau $65,808 \%$ per tahun.

c) Introduksi alat Vaccum Frying, Spinner dan Teknologi Pengemasan ke mitra

Untuk meningkatkan pengetahuan mitra UKM, maka terlebih dahulu dilakukan kegiatan pengenalan ala tvaccum frying dan spinner. Kegiatan ini dilakukan dengan memberikan penjelasan kepada mitra tentang komponen-komponen alat, cara pengoperasian, perawatan dan pemeliharaan. Disamping menggunakan metode ceramah dan demonstrasi, kegiatan ini juga memberikan kesempatan kepada mitra untuk bertanya dan berdiskusi mengenai komponen dan cara penggunaan alat. Gambar 6 memperlihatkan kegiatan introduksi alat ke mitra.

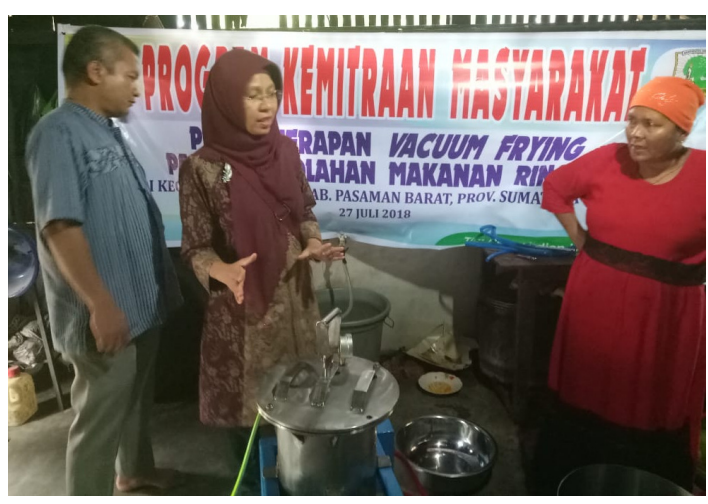

Gambar 6. Kegiatan introduksi alat ke mitra

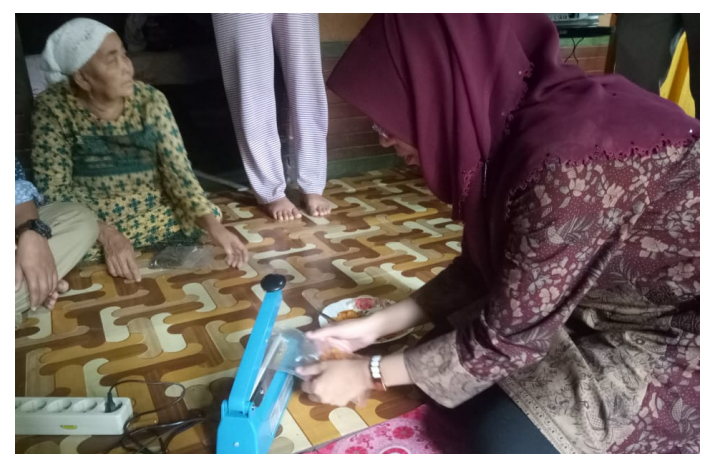

Gambar 7.Kegiatan demonstrasi penggunaan hand sealer
Dalam rangka meningkatkan program pemasarannya, UKM juga mendapatkan pengetahuan mengenai pengemasan dan pelabelan produk. UKM mitra dilatih menggunakan hand sealer, agar bisa mengemas produk dengan lebih menarik. Mtra juga mendapatkan pengetahuan mengenai merek atau label agar konsumen dapat mengetahui produk yang dihasilkan mitra UKM. Gambar 7 memperlihatkan kegiatan demontrasi pengemasan menggunakan hand sealer. Secara umum, kegiatan introduksi ini berjalan dengan lancar dan mitra tertarik sekali dengan adanya pengenalan dan penerapan teknologi ini. Diharapkan kedepannya, mitra dapat melakukan pengemasan produk yang lebih menarik bagi konsumen.

\section{KESIMPULAN}

Kesimpulan dari pelaksanaan kegiatan pengabdian ini adalah sebagai berikut

1. Introduksi alat vaccum frying telah menambah pengetahuan mitra dalam mendiversifikasikan produk olahan mereka dengan memanfaatkan bahan baku yang ada disekitar mitra.

2. Introduksi spinner dapat membantu meningkatkan kualitas produk keripik yang selama ini telah dilakukan oleh mitra.

3. Tranfer teknologi pengemasan dapat membantu mitra dalam melakukan pengemasan produk dengan lebih menarik sehingga diharapkan dapat meningkatkan pemasaran produk. 


\section{SARAN}

Percobaan yang berulang-ulang dengan menggunakan alat vaccum frying perlu dilakukan untuk bahan baku yang berbeda agar menghasilkan keripik yang dapat diterima konsumen.

\section{UCAPAN TERIMAKASIH}

Penulis mengucapkan terimakasih kepadaDirjen Penguatan Riset dan Pengembangan, Kementerian Riset, Teknologi dan Pendidikan Tinggi sesuai dengan Surat Perjanjian Pelaksanaan Pangabdian Masyarakat tahun anggaran 2018 Nomor:

02/UN.16.17/X111.PM.PKM/LPPM/2018 atas sumber dana yang diberikan untuk pelaksanaan kegiatan pengabdian kepada masyarakat dalam skim PKM.

\section{REFERENSI}

[BPS] Badan Pusat Statistik Kabupaten Pasaman Barat. 2017. Statistik Daerah Kecamatan Koto Balingka. Badan Pusat Statistik Kabupaten Pasaman Barat.

[BSN] Badan Standarisasi Nasional. 1992. SNI 01-2602-1992. Keripik Tempe Goreng.

[BSN] Badan Standarisasi Nasional. 1996. SNI 01-4279-1996. Keripik Sukun.

[BSN] Badan Standarisasi Nasional. 1996. SNI 01-4305-1996. Keripik Singkong.

[BSN] Badan Standarisasi Nasional. 1996. SNI 01-4315-1996. Keripik pisang.

Elinda Y. 2007. Produksi keripik daging dengan perlakuan jenis tepung yang digoreng vakum. Tesis. IPB. Bogor.

Garayo J dan Moreira RG. 2002. Vacuum frying of potato chips. J. of Food Processing Engineering. 55(2):181-191.

Granda C, Moreira RG, Tichy SE. 2004. Reduction of acrylamide formation in popato chips by low-temperature cacuum frying. Journal of Food Science. 69(8): E405-E411.

Lastriyanto A. 1997. Penggorengan Buah secara Vakum (Vaccum frying) dengan Menerapkan Pemvakuman Water Jet. Temu Ilmiah serta Ekspos Alat dan Mesin Pertanian. Cisarua Bogor 27 Februari 1997

Rukmana R. 1995. Terung. Kanisius. Yogyakarta.

Setyawan N. dan Widaningrum. 2013. Pengaruh suhu penggorengan vakum dan cara pembumbuan terhadap karakteristik keripik wortel. J. Pascapanen. 10 (2): 106115.

Setyawan, N., Widaningrum, D.A. Setyabudi, M. Shaffah, Siswadi, Tisnawati. 2007. Teknologi Pengolahan Sayuran Kering Siap Santap. Laporan Akhir Penelitian. Balai Besar Litbang Pascapanen Pertanian. Departemen Pertanian.

Shyu S.-L, Hau L., Hwang LS. 1998. Effect of vacuum frying on the oxidative stability of oils. Journal of the American Oil Chemists'Society. 75:1393-1398.

Shyu S.-L. dan Hwang L. S. 2001. Effects of processing conditions on the quality of vacuum fried apple chips. Food Research International.34: 133-142.

Troncoso E dan Pedreschi F. 2009. Modeling water loss and oil uptake during vacuum frying of pre-treated potato slices. Journal of Food Science and Technology. 42(6):1164-1173.

Widaningrum dan Setyawan N. 2009. Standarisasi keripik sayuran (wortel) sebagai upaya peningkatan daya saing produk olahan hortikultura. Jurnal Standardisasi [ js.bsn.go.id]. 